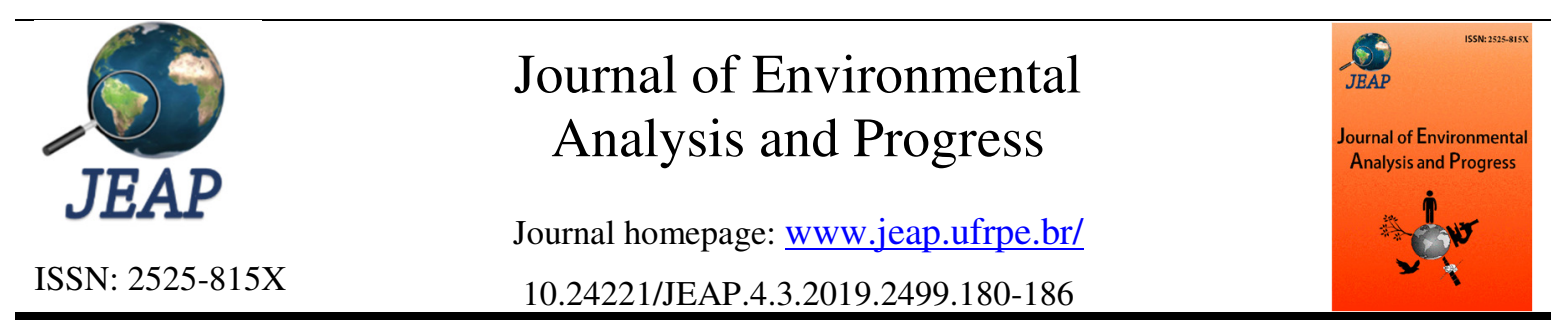

\title{
Effects of Myroxylon peruiferum L. f. organic extracts in planktonic growth and Ralstonia solanacearum biofilm formation
}

Carolina Barbosa Malafaia $a^{a^{*}}$, Laureen Michelle Houllou ${ }^{\mathrm{a}}$ Mariana Oliveira Barbosa ${ }^{\mathrm{b}}$, Elineide Barbosa de Souzac ${ }^{c}$, Alexandre José Macedo ${ }^{\mathrm{d}}$, Alexandre Gomes da Silva ${ }^{\mathrm{e}}$, Maria Tereza dos Santos Correia ${ }^{\mathrm{e}}$, Márcia Vanusa Silva ${ }^{\mathrm{e}}$

${ }^{\text {a }}$ Centro de Tecnologias Estratégicas do Nordeste-CETENE, Av. Prof. Luís Freire, n. 01, Cidade Universitária, Recife, PE, Brasil. CEP: 50.740-540. *Corresponding author: carol08malafaia@ hotmail.com.

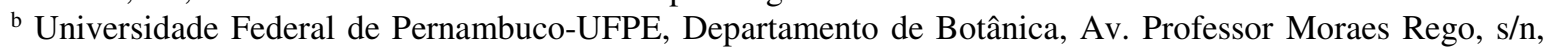
Recife, PE, Brasil. CEP: 50.670-420.

${ }^{\mathrm{c}}$ Universidade Federal Rural de Pernambuco-UFRPE, Departamento de Biologia, Área de Microbiologia, Rua Dom Manoel de Medeiros, s/n, Dois Irmãos, Recife, PE, Brasil. CEP: 52.171-900.

${ }^{\text {d }}$ Universidade Federal do Rio Grande do Sul-UFRGS, Faculdade de Farmácia e Centro de Biotecnologia, Av. Ipiranga, 2752, Porto Alegre, RS, Brasil. CEP: 90.610-000.

e Universidade Federal de Pernambuco-UFPE, Departamento de Bioquímica, Av. Professor Moraes Rego, 1235, Recife, PE, Brasil. CEP: 50.670-420.

\section{A R T I C L E I N F O}

Received 29 Apr 2019

Accepted 04 Jul 2019

Published 05 Jul 2019

\begin{abstract}
A B S T R A C T
Ralstonia solanacearum, a causal agent of bacterial wilt, a disease with significant negative impacts on world agriculture, presents considerable difficulties in handling due to its resistance to the common forms of control. Based on this context, the objective was to investigate alternative substances for biofilm control and planktonic growth of this phytopathogen. Four organic extracts in the eluotropic series (cyclohexane, chloroform, ethyl acetate, and methanol) of Myroxylon peruiferum collected in the Caatinga were evaluated for antibiofilm and antibacterial activity using the crystal violet method and antibacterial activity in microplates, considering positive values greater than $50 \%$ inhibition. The organic extracts were evaluated qualitatively by thin layer chromatography. Results obtained showed that antibiofilm activity was detected in the cyclohexanic extract, whereas ethyl acetate extract showed antibiotic activity, both in the minimum inhibitory concentration of 3 $\mathrm{mg} \cdot \mathrm{mL}^{-1}$. The evaluation presented in this study provides a database for the development of new natural phytopathogen control agents.

Keywords: Phytopathogen, antibiofilm, antimicrobial, Perú balsam.
\end{abstract}

\section{Introduction}

Ralstonia solanacearum is a gramnegative quickly and fatal phytopathogen that colonizes the vascular system of various crops that could cause relevant economic damage (Meng, 2013; Yuliar et al., 2015). The bacterium beginning infection cycle start in the roots and, when reaching the vessels of xylem, colonizes, and produces large amounts of exopolysaccharides (EPS) (Mansfield et al., 2012). It was well known that the biofilm formation in the vessels walls, by EPS deposit, interfere in the plant water flow, causing wilt symptoms and, consequently, plant death (Ramey et al., 2004; Mansfield et al., 2012). For being an endophyte pathogen, able to infect weeds, the traditional control methods applied seems ineffective for this phytopathogen (Yuliar et al., 2015).

In recent years, the biofilm production was appointed as one of the most relevant virulence factors of many phytopathogens, including $R$. solanacearum (Ramey et al., 2004; Joe et al., 2015; Guerra et al., 2018). The biofilm production is possibly related to microorganism mechanisms that conferee physiological advantages as: tolerance to unfavorable environmental conditions, to an abiotic conditions (such as water and nutrient shortages), to a drastic and sudden alterations of $\mathrm{pH}$, to biotic as interspecific competition resistance to host-produced defenses (such as the production of antimicrobials) (Dow et al., 2003; Muranaka et al., 2012). The biofilm matrix structure is 
composed mainly of exopolysaccharides, proteins and extracellular DNA, and this is responsible for conferring resistance to microorganisms (Stoodley et al., 2002; Trentin \& Macedo, 2013; Malafaia et al., 2017).

The relevance of secondary metabolites, natural molecules biosynthesized by plants, has been exhaustively exploited on several biological applications. Plants produce these compounds in response to environmental conditions such as high temperatures, high incidence of UV light, high concentrations of salts in the soil and restricted water availability (Essawi \& Srour, 2000) and or as a response to interactions with pathogenic or nonpathogenic microorganisms (Trentin \& Macedo, 2013). Thus, compounds derived from plants have been highlighted in studies seeking forms of pathogens alternative control, in the intent of replacing the use of synthetic molecules harmful to health and the environment (Essawi \& Srour, 2000; Venturoso et al., 2011).

However, most of the researches with plant bioactives try to investigate the effects of these compounds against planktonic bacteria. Little has been verified about the biofilms life form that could have antimicrobials compounds resistance and, therefore, are more difficult to control and eradicate (Sandasi et al., 2010). Finding new antibacterial compounds, with alternative mechanisms of action, such as acting on the formation of the bacterial biofilm, constitute a promising alternative to pathogenic microorganisms control (Silva et al., 2015). According to some research, the Caatinga ecosystem presents some environmental conditions that could be favorable for investigating a wide range of bioactive compounds that can be used for this purpose.

In a matter of fact, a significant variety of plant-derived compounds have been increasingly identified by being effective in controlling various human pathogens (Kawsud et al., 2014; Nikolić et al., 2014), however little is known of its efficacy against phytopathogenic agents. As so, the objective of this study was to investigate the effects of four organic extracts of Myroxylon peruiferum, collected in the Caatinga ecosystem, on bacterial growth and biofilm formation of $R$. solanacearum.

\section{Material and Methods \\ Plant material \\ The plant material was collected at the Catimbau National Park, Pernambuco, Brazil, in November 2014. The species were identified in the Instituto Agronômico de Pernambuco (IPA) herbarium under voucher number 84.110.}

The samples preparation for organic extraction of $M$. peruiferum leaves were initiated with dried tissue samples at $40^{\circ} \mathrm{C}$ for 3 to 4 days. Subsequently, the material was pulverized in a blender.

\section{Organic extracts}

One hundred (100) grams of dried and crushed leaves of M. peruiferum were subjected to organic extraction using eluotropic series solvents (cyclohexane, chloroform, ethyl acetate, and methanol) sequentially under the same mass of leaves in Soxhlet $\left(45\right.$ to $80^{\circ} \mathrm{C}$ ) refluxed to saturation. The extracts were then filtered and further concentrated until the solvent was removed in a rotary evaporator at $45^{\circ} \mathrm{C}$ under reduced pressure. The extracts were then analyzed for phytochemistry and antimicrobial activity.

\section{Phytochemical screening}

The organic extracts obtained were evaluated for the presence of secondary metabolites. The of alkaloids classes identification, triterpenes, flavonoids, and tannins were performed by thin layer chromatography (TLC) using silica gel plate (Merck), according to Wagner \& Bladt (Wagner \& Bladt, 2009) and the presence of saponins was evaluated according to Silva et al. (2010).

\section{Bacterial isolate and culture conditions}

Ralstonia solanacearum isolate CGH8 was used as strong biofilm formers microorganism. This isolate was obtained from Phytobacteriology Laboratory Culture Collection (Agronomy Department of the Universidade Federal Rural de Pernambuco-UFRPE, Brazil), where they were initially isolated, identified and biochemically characterized.

The CGH8 isolate was grown in nutrient yeast dextrose agar NYDA $\left(5\right.$ g.L $\mathrm{L}^{-1}$ yeast extract, 3 g.L $\mathrm{L}^{-1}$ meat extract, 5 g.L $\mathrm{L}^{-1}$ peptones, 10 g.L. $\mathrm{L}^{-1}$ dextroses, and 18 g.L. $\mathrm{L}^{-1}$ Agar) during $24 \mathrm{~h}$, at $28^{\circ} \mathrm{C}$, and a bacterial suspension in $0.9 \% \mathrm{NaCl}$, corresponding to $1 \mathrm{McF}$ arland scale commercial (3 $\times 10^{8} \mathrm{CFU} \cdot \mathrm{mL}^{-1}$ ), was used in the assays.

\section{Antibiofilm and antibacterial assays}

The evaluation of antibiofilm activity was according to Malafaia et al. (2017), employing the technique by staining with violet crystal in microbiological tests carried out in microtitler plates sterile 96-well polystyrene flat-bottom (Costar 3599) purchased from Corning Inc. (USA) was used. Forty microliters of the bacterial suspension, $20 \mu \mathrm{l}$ of the organic extract (concentration of $0.5 \mathrm{mg} \cdot \mathrm{mL}^{-1}$ to $4 \mathrm{mg} \cdot \mathrm{mL}^{-1}$ ) and 
$140 \mu \mathrm{l}$ of medium broth nutrient yeast dextrose (NYD) were added at well microtiter plates and posteriorly incubated at $28^{\circ} \mathrm{C}$ for $24 \mathrm{~h}$. The content of the wells was removed, and the wells were washed three times with sterile saline. The remaining attached bacteria were heat-fixed at $60^{\circ} \mathrm{C}$ for one hour. The adherent biofilm layer formed was stained with $0.4 \%$ crystal violet for 15 min at room temperature. The stain bound to the cells was solubilized with $99.5 \%$ ethanol, and after $30 \mathrm{~min}$, the absorbance was measured at $570 \mathrm{~nm}$ (Spectramax M2e Multimode Microplate Reader, Molecular Devices, USA). The biofilm formation control was considered to represent $100 \%$ of biofilm formation, and the extracts were replaced by $20 \mu \mathrm{l}$ of water in 96-well microtiter plates. Values higher than $100 \%$ represent a stimulation of biofilm formation in comparison to the control.

The planktonic bacterial growth was evaluated by the difference between the OD600 absorbance measured at the end and at the beginning of the incubation time in polystyrene 96well microtiter plates. As a control for bacterial growth, the extracts were replaced by $20 \mu \mathrm{l}$ of water, with this being considered to represent $100 \%$ of planktonic bacterial growth. Values higher than $100 \%$ represent a stimulation of bacterial growth in comparison to the control. Rifampicin $(32 \mu \mathrm{M})$ was used as antibiotic control.

\section{Statistical Analysis}

Microbiological tests were performed at least in biological quadruplicate and experimental triplicate. The chemical tests were performed in triplicate. The results were expressed as a percentage of mean \pm standard deviation. Differences between groups were evaluated by Student's T-test, and the values were considered statistically significant if compared to the significance level of $\mathrm{p}<0.05$.

\section{Results}

The use of methanol was less efficient to obtain alkaloids, coumarins, and triterpenes. On the other hand, this was the only solvent to extract saponins and tannins from the plant samples. It was also observed that the solvents cyclohexane, chloroform, and ethyl acetate had similar behavior, isolating the same group of substances (coumarins, flavonoids, and triterpenes). This result indicates a similarity of efficiency among these extractive compounds.
However, as the effect of the extracts presented the difference between them, during the analysis of biofilm formation and cellular growth, the results indicate that all concentrations tested with the cyclohexane extract stimulated cell growth (multiplication). On the other hand, only the higher concentration $\left(4.0 \mathrm{mg} \cdot \mathrm{mL}^{-1}\right)$ of the extract, tested with ethyl acetate, presented a stimulating effect on cell multiplication. This increase, observed with extracts obtained with methanol, is related to the level of the organic extract used. The lowest dose tested $\left(0.5 \mathrm{mg} \cdot \mathrm{mL}^{-1}\right)$ of the organic extract obtained with methanol do not affect biofilm or cell multiplication.

Although the organic extract obtained with cyclohexane has stimulated cell multiplication, somehow biofilm formation was inhibited. It was expected that with increasing cell multiplication, there would be an increase in biofilm formation. However, this correlation (increase in cell multiplication and increase in biofilm formation) was observed only at the concentration of 4.0 mg. $\mathrm{mL}^{-1}$ of the organic extract obtained with methanol.

Figure 1 shows the screening of the antimicrobial and anti-biofilm activities of the organic extracts of leaves of $M$. peruiferum against a strong biofilm former CGH8 isolate of $R$. solanacearum (Malafaia et al., 2018). The results show that ethyl acetate extract at $3 \mathrm{mg} \cdot \mathrm{mL}^{-1}$ was able to inhibit bacterial growth in $53.5 \%$. However, $3 \mathrm{mg} \cdot \mathrm{mL}^{-1}$ concentration did not affect biofilm formation and had no significant difference when compared to the control.

The antibiofilm activity was observed in the extract of cyclohexane that inhibited the formation of biofilm (reduction biofilm formation over 50\% compared to control), without a statistical difference between $3 \mathrm{mg} \cdot \mathrm{mL}^{-1}(54.1 \%)$ and 4 mg. $\mathrm{mL}^{-1}(63.7 \%)$, determining a minimum inhibitory concentration of $3 \mathrm{mg} \cdot \mathrm{mL}^{-1}$ for a mechanism that does not involve bacterial death. In this concentration $\left(3 \mathrm{mg} \cdot \mathrm{mL}^{-1}\right)$ was observed a stimulus to cell growth (an increase of up to 115\%).

The preliminary qualitative phytochemical screening of these extracts can be observed in Table 1, which indicates the presence of flavonoids, coumarins, and triterpenes in all extracts. However, only in the methanolic extract showed the presence of saponins and tannins. 
Figure 1. Pure culture biofilm formation assay in nutrient yeast dextrose (NYD) in the presence of organic extracts of Myroxylon peruiferum isolate CGH8. Biofilm formation, ${ }^{-}$bacterial growth of Ralstonia solanacearum. The bars represent the mean values $(\mathrm{n}=12)$. Lowercase letters and capital letters indicate significant differences $(\mathrm{p}<0.05)$ in planktonic growth and biofilm formation, respectively.

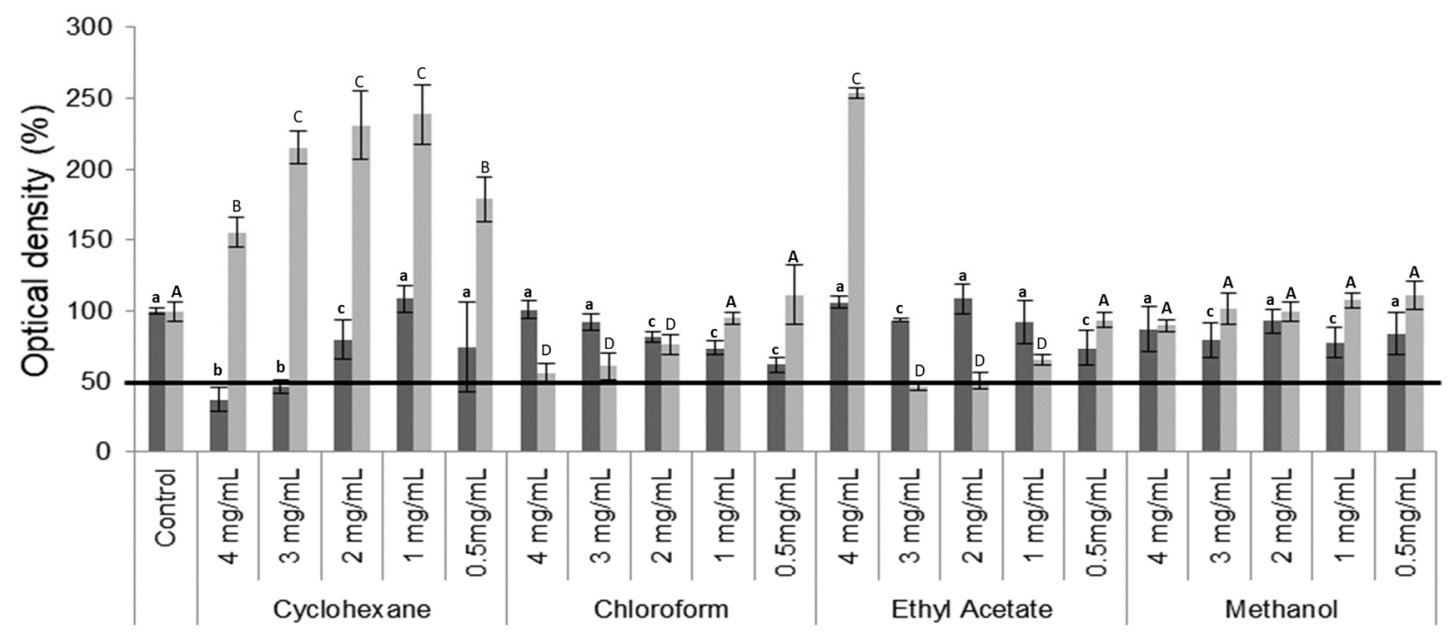

Organic Extracts

Table 1. Phytochemical analysis of organic extracts of leaves of Myroxylon peruiferum.

\begin{tabular}{lcccc}
\hline \multirow{2}{*}{ Class of compounds } & \multicolumn{5}{c}{ Extracts } \\
& CH & $\mathbf{C F}$ & $\mathbf{E A}$ & $\mathbf{M}$ \\
\hline Alkaloids & - & - & - & - \\
Coumarins & + & + & + & - \\
Flavonoids & + & + & ++ & +++ \\
Saponins & - & - & - & + \\
Tannins & - & - & - & + \\
Triterpenes & ++ & +++ & ++ & - \\
\hline
\end{tabular}

(-) Absence, $(+)$ weak, $(++)$ average, $(+++)$ Strong. CH: Cyclohexane, CF: Chloroform, EA = Ethyl Acetate, $\mathrm{M}=$ Methanol

\section{Discussion}

The use of synthetic molecules in agriculture has been less and less recommended by environmentalists and the World Health Organization (WHO) due to its high toxicity to man and the environment (Minz, 2012). Besides, an increase in the resistance of plant pathogenic microorganisms has been verified, provoking an increase in the use of such toxic substances. Many studies report the antibacterial activity of plant extracts against human pathogens and their pharmaceutical application (Gibbons, 2004), but little is known about this activity against phytopathogens. A new alternative in the control of bacterial diseases is through the inhibition of biofilm formation since this is shown as a strategy of resistance and permanence in the environment (Rasko \& Sperandio, 2010; Silva et al., 2015). The result obtained in this study indicates that $M$. peruiferum organic extract probable have some compounds that affect this bacterium development.
New molecules with described biological activities, including antimicrobials, have been obtained from various plant species (Mutalib et al., 2015). M. peruiferum is used medicinally as an anti-inflammatory and expectorant pectoral, used in cases of asthma, bronchitis asthma, cystitis, lung disease, headache, external wound, weakness, sore throat, cough and airway symptoms (Lorenzi \& Mattos, 2008). Hydroalcoholic extracts of $M$. peruiferum have also been reported to have a higher amplitude of antibacterial activity against Streptococcus pyogenes, Shigella sonnei and Staphylococcus aureus (Gonçalves et al., 2005) and aqueous extracts have already demonstrated positive activity against the biofilm formation of $R$. solanacearum (Malafaia et al., 2017), however, a potential antimicrobial activity has not yet been described against this phytopathogen. The results obtained showed that organic extracts could present different effects on $R$. solanacearum development. 
According to the extraction procedure, the organic extract could reduce cell multiplication or stimulate it, the latter being mainly observed in the extract of cyclohexane. These results indicate that not only the sources of compounds are relevant to the identification of new substances against biofilm and cell multiplication, but the process of extracting could be a critical factor to consider.

The bacterial biofilm undergoes five stages of development according to Sauer (2003): Reversible cell adhesion; Irreversible cell adhesion; Biofilm maturation begins; Fully mature biofilm with complex architecture; Biofilm disruption, and cell dispersion. Several processes are involved in the formation of biofilm, starting with surface adhesion. It is crucial for the establishment of the biofilm, so any molecule, or set of these, that will interfere negatively in this process, is considered antibiofilm. Thus, the extracts that showed activity possibly interfere in the adhesion of the bacterium to the surface.

Generally, the organic fractions present higher biological activity than those observed in the aqueous fraction in the biofilm inhibition of bacteria species (Mutalib et al., 2015). However, when the results obtained in this study are compared with those obtained by Malafaia et al. (2017) this did not happen, suggesting that the separation of compounds caused by the fractionation of the eluotropic series may have separated components that increase the antibiofilm activity when in synergism.

Preliminary phytochemical screening of the active extract of $M$. peruiferum leaves revealed the presence of coumarins, flavonoids and triterpenoids, secondary metabolites produced by plants that, among other functions, are used in defense against phytopathogens (Cowan, 1999). Flavonoids and coumarins are the largest groups of substances extracted from plants with reported antimicrobial activity (Cowan, 1999). These chemical classes of secondary metabolites have already been described as active for antibiofilm as verified by Riihinen et al. (2014). In this case, flavonoids isolated from Vaccinium vitis-idaea were active against the biofilm formation of $S$. mutans and Fusobacterium nucleatum. Awolola et al. (2014) described that flavonoids and purified triterpenes of Ficus sansibarica presented antibacterial activity and antibiofilm against $S$. aureus and Escherichia coli. According to the results, it is possible that despite the same group of compounds is present in each extract; subfractions of the same compound family could be obtained by the extracting processes used. However, the validation of this result will depend on finer analyzes.

\section{Conclusion}

Most of the plants have antimicrobial properties, and this fact makes them essential in the researches to develop new bioactive compounds safe for man and the environment, presenting effectiveness in the protection of economically important species. M. peruiferum, plant used for medicinal purposes, contain phytochemicals effective in inhibiting the formation of biofilm also for phytopathogens. The antibiofilm action of the extracts of this plant against $R$. solanacearum probably is associated with the inhibition of the cellular adhesion process. The in vitro screening is important to guide the development of new products in addition to overseeing bioactive compound prospecting studies.

\section{Acknowledgements}

The authors would like to acknowledge Brazilian agencies and companies that have supported this research: Coordenação de Aperfeiçoamento de Pessoal de Nível Superior (CAPES), Fundação de Amparo à Ciência e Tecnologia do Estado de Pernambuco (FACEPE), Fundação de Amparo à Pesquisa do Estado do Rio Grande do Sul (FAPERGS), and Conselho Nacional de Desenvolvimento Científico e Tecnológico (CNPq).

\section{References}

AWOLOLA, G. V.; KOORBANALLY, N. A.; CHENIA, H.; SHODE, F. O.; BAIJNATH, H. 2014. Antibacterial and anti-biofilm activity of flavonoids and triterpenes isolated. Afr. J. Tradit. Complement Altern. Med., v. 3, n. 11, p. 124-131.

COWAN, M. M. 1999. Plant products as antimicrobial agents. Clin. Microbiol. Rev., v. 12, n. 4 , p. 564-82.

DOW, J. M.; CROSSMAN, L.; FINDLAY, K.; HE, Y. Q.; FENG, J. X.; TANG, J. L. 2003. Biofilm dispersal in Xanthomonas campestris is controlled by cell-cell signaling and is required for full virulence to plants. Proc. Natl. Acad. Sci. U. S. A., v. 100 , n. 19 , p. 10995-11000.

ESSAWI, T.; SROUR, M. 2000. Screening of some Palestinian medicinal plants for antibacterial activity. J. Ethnopharmacol., v. 70, n. 3, p. 343349.

GIBBONS, S. 2004. Anti-staphylococcal plant natural products. Nat. Prod. Rep., v. 21, n. 2, p. 263-277.

GONÇALVES, A. L.; ALVES FILHO, A.; 
MENEZES, H. 2005. Estudo comparativo da atividade antimicrobiana de extratos de algumas árvores nativas. Arq. Inst. Biol., v. 72, n. 3, p. 353358.

GUERRA, M. L.; MALAFAIA, C. B.; MACEDO, A. J.; SILVA, M. V.; MARIANO, R. L. R.; SOUZA, E. B. 2018. Biofilm formation by Xanthomonas campestris pv. viticola affected by abiotic surfaces and culture media. Trop. Plant Pathol., v. 43, n. 2, p. 146-151.

JOE, M. M.; BENSON, A.; SARAVANAN, V. S.; SA, T. 2015. In vitro antibacterial activity of nanoemulsion formulation on biofilm, AHL production, hydrolytic enzyme activity, and pathogenicity of Pectobacterium carotovorum sub sp. carotovorum. Physiol. Mol. Plant Pathol., v. 91, p. $46-55$.

KAWSUD, P.; PURIPATTANAVONG, J.; TEANPAISAN, R. 2014. Screening for anticandidal and antibiofilm activity of some herbs in Thailand. Trop. J. Pharm. Res., v. 13, n. 9, p. 1495-1501.

LORENZI, H.; MATTOS, F. J. A. 2008. Plantas medicinais no Brasil: nativas e exóticas, 2nd. ed. Nova Odessa-SP.

MALAFAIA, C. B.; BARROS, M. P. DE; MACEDO, A. J.; GUERRA, M. DE L.;SOUZA, E. B. DE; CORREIA, M. T. DOS S.; SILVA, M. V. 2018. Biofilm Formation by Phytopathogenic Bacteria Acidovorax citrulli and Ralstonia solanacearum. J. Environ. Anal. Prog., v. 3, n. 4, p. 347-355.

MALAFAIA, C. B.; JARDELINO, A. C. S.;SILVA, A. G.; SOUZA, E. B. DE; MACEDO, A. J.; CORREIA, M. T. DOS S.; SILVA, M. V. 2017. Effects of Caatinga Plant Extracts in Planktonic Growth and Biofilm Formation in Ralstonia solanacearum. Microb. Ecol., v. 75, n. 3, p. 555-561.

MANSFIELD, J.; GENIN, S.; MAGORI, S.; CITOVSKY, V.; SRIARIYANUM, M.; RONALD, P.; DOW, M.; VERDIER, V.; BEER, S. V.; MACHADO, M. A.; TOTH, I.; SALMOND, G.; FOSTER, G. D. 2012. Top 10 plant pathogenic bacteria in molecular plant pathology. Mol. Plant Pathol., v. 13, n. 6, p. 614-629.

MENG, F. 2013. The Virulence Factors of the Bacterial Wilt Pathogen Ralstonia solanacearum. J. Plant Pathol. Microbiol., v. 4, n. 3, p. 3-5.
MINZ, S. 2012. The Effect of Plant Extracts on the Growth of Wilt Causing Fungi Fusarium oxysporum. J. Pharm. Biol. Sci., v. 4, n. 1, p. 1316.

MURANAKA, L. S.; TAKITA, M. A.; OLIVATO, J. C.;KISHI, L. T.; DE SOUZA, A. A. 2012. Global expression profile of biofilm resistance to antimicrobial compounds in the plant-pathogenic bacterium Xylella fastidiosa reveals evidence of persister cells. J. Bacteriol., v. 194, n. 17, p. 45614569.

MUTALIB, L. Y.; NURADDIN, S. M.; TOMA, S.; AKA, H. 2015. Phytochemical screening, antibacterial and antibiofilm evaluation of Lagenaria siceraria fruit growing in Kurdistan RegionUIraq. J. Pharmacogn. Phytochem., v. 4, n. 1, p. 45-49.

NIKOLIĆ, M.; VASIĆ, S.; DURDEVIĆ, J.;STEFANOVIĆ, O.; ČOMIĆ, L. 2014. Antibacterial and anti-biofilm activity of Ginger (Zingiber officinale (Roscoe)) ethanolic extract. Kragujev. J. Sci., v. 36, n. 581, p. 129-136.

RAMEY, B. E.; KOUTSOUDIS, M.;BODMAN, S. B. VON; FUQUA, C. 2004. Biofilm formation in plant-microbe associations. Curr. Opin. Microbiol., v. 7, n. 6, p. 602-609.

RASKO, D. A.; SPERANDIO, V. 2010. Antivirulence strategies to combat bacteria-mediated disease. Nat. Rev. Drug Discov., v. 9, n. 2, p. 117128.

RIIHINEN, K. R.; OU, Z. M.; GÖDECKE, T.; LANKIN, D. C.; PAULI, G. F.; WU, C. D. 2014. The antibiofilm activity of lingonberry flavonoids against oral pathogens is a case connected to residual complexity. Fitoterapia, v. 97, p. 78-86.

SANDASI, M.; LEONARD, C. M.; VILJOEN, A. M. 2010. The in vitro antibiofilm activity of selected culinary herbs and medicinal plants against Listeria monocytogenes. Lett. Appl. Microbiol., v. 50, n. 1, p. 30-35.

SAUER, K. 2003. The genomics and proteomics of biofilm formation. Genome Biol., v. 4, n. 9, p. 219.1-219.5.

SILVA, L. N.; TRENTIN, D. DA S.; ZIMMER, K. R.; TRETER, J.; BRANDELLI, C. L. C.; FRASSON, A. P.; TASCA, T.; SILVA, A. G. DA; 
SILVA, M. V. DA; MACEDO, A. J. 2015. Antiinfective effects of Brazilian Caatinga plants against pathogenic bacterial biofilm formation. Pharm. Biol., v. 53, n. 3, p. 464-468.

STOODLEY, P.; SAUER, K.; DAVIES, D. G.; COSTERTON, J. W. 2002. Biofilms as complex differentiated communities. Annu. Rev. Microbiol., v. 56, n. 8, p. 187-209.

TRENTIN, S.;MACEDO, A. J. 2013. Biofilmes bacterianos patogênicos: aspectos gerais, importância clínica e estratégias de combate. Rev.
Lib., v. 14, n. 22, p. 113-238.

VENTUROSO, L. R.; GAVASSONI, W. L.; CONUS, L.A.; SOUZA, F. R. 2011. Inibição Do Crescimento in Vitro De Fitopatógenos Sob Diferentes Concentrações de Extratos de Plantas Medicinais. Arq. Inst. Biol., v. 78, n. 1, p. 89-95.

YULIAR; NION, Y. A.; TOYOTA, K. 2015. Recent trends in control methods for bacterial wilt diseases caused by Ralstonia solanacearum. Microbes Environ., v. 30, n. 1, p. 1-11. 